\section{BOOTS AND SHOES FROM HISTORICAL AND SURGICAL POINTS OF VIEW. ${ }^{1}$}

BY E. MUIRHEAD LITTLE, F.R.C.S. ENG., SENIOR SURGEON TO THE ROYAL NATIONAL ORTHOP ADIC HOSPITAL.

THE subject of footgear is not perhaps a lofty one nor of scientific intricacy, but as the comfort of millions of people depends (among other things) upon how they are shod, and as ill-shaped and illfitting boots and shoes cause a huge amount of discomfort and pain, some discussion of the subject may be interesting and profitable.

The custom of wearing some form of foot covering is much older than history, and probably it dates from the dawn of civilisation; for although to-rlay there are still primitive peoples who do not wear any shoes or sandals, yet the earliest pictorial and written records represent men as shod. In various museums there are shoes still existing which are as much as 3500 years old. In the British Museum, for instance, there are a number of Egyptian shoes and sandals some of which must have been made as long ago as the year 1600 B.C.

It is a somewhat remarkable fact that, despite the antiquity of boots and shoes, very few books on the subject of footgear have appeared. That distinguised Dutch physician and naturalist, Peter Camper, whose versatility has been made a reproach by some of his biographers, turned his attention to this question, but it originated in a joke, and it was more as an exhibition of his own skill than as a serious study of the question that he wrote his dis. sertation, "Sur la Meilleure Forme des Souliers," which was published about 1781 without date or place on the title-page. Plenty of writers have treated of the feet of beasts, he says, but no one of the human foot. Yet, he goes on to say, our feet have suffered from the shoes which deform them for centuries, for Cornelius Celsus, who wrote in the age of Tiberius, and Paulus of Egina, who flourished in the second century after Christ, and Aetius Amidenus have described the maladies of the feet caused by ill-made shoes and sandals. Most anatomists, he said, had represented deformed toes in their plates of the skeleton of the foot. Camper had a great reputation as a naturalist and man of science, but he seems to have had very little real knowledge of the anatomy and functions of the foot.

In the last century a non-medical writer, the distinguished French antiquarian, Viollet-le-Duc, described the footgear in use in France from the twelfth to the sixteenth centuries. ${ }^{2}$ Lately several American surgeons have published valuable papers on boots and shoes and their relation to the feet. Among these, the work of Dr. Sampson, of Baltimore, and of Dr. Hoffman, of St. Louis, are worthy of study.

It is well to mention some points in the anatomy and physiology of the foot, which should be borne in mind when considering the question of footwear. The ankle is a hinge-joint between the tibia and fibula above and the astragalus below. It allows of no movement but simple flexion and extension, whereas the joints of the tarsus, and notably the joints between the astragalus above and the os calcis and scaphoid and cuboid below, allow of movements of rotation,

1 Founded on a lecture delivered at the Medical Graduates' College and Polyclinic, London.

2 Dictionnaire Rais-onné du Mobilier Francais de l'époque Carlovingienee à la Renaissance, par M. Viollet-le-Duc, Architecte vingienee à la Renaissance,
Deuxieme edition, Paris, 1868 . abduction and adduction, and flexion and extension. Owing to the arrangement of the bones and ligaments of the tarsus the movements below the ankle are all complex. Adduction is always associated with outward rotation, in which the arch is increased (varus), while abduction is associated with rotation inwards, in which the arch is decreased and the sole flattened (valgus). The astragalus, as a German writer, Starke, has aptly said, "rides on the calcaneum as a lady rides on a side-saddle," and when the foot is turned out and thereby simultaneously rotated inwards and the inner border of the os calcis lowered, the riding astragalus, like some ladies, is apt to slip over sideways and down. wards.

In the normal foot, unaffected by boots, a straight line drawn through the middle line of the phalanges of the great toe and prolonged backwards passes through the middle of the heel-that is to say, the great toe is adducted (drawn towards the middle line of the body, not towards the middle line of the foot). Some confusion has been caused by the habit of describing the so-called arch of the foot as though it were an arch in the architectural sense. This, as I have pointed out elsewhere, ${ }^{3}$ it is not.

The foot has not only to support the weight of the body, but it has to act as a lever, as in running on tiptoes, or when in walking a push-off is given with the toe of the hinder foot. It has also to bear tremendous shocks in its capacity of buffer, as in jumping from a height. This important buffer action protects the great nerve centres and the other important structures of the trunk and saves the knee- and hip-joints from too severe strains. In addition to these important functions the normal foot of barefooted peoples has that of grasping. The native artisans of India, for instance, make great use of their toes to hold or steady their work, but boots and shoes have destroyed this function in most civilised adults.

The normal foot is said to have two arches, a longitudinal and a transverse one, which combined form a semi-vault. There is also a transverse arch formed by the heads of the metatarsal bones, which, however, disappears as soon as the weight of the body falls on the front of the foot. It is further worthy of note that although the normal great toe can be voluntarily adducted and abducted, there is

FIG. 1.

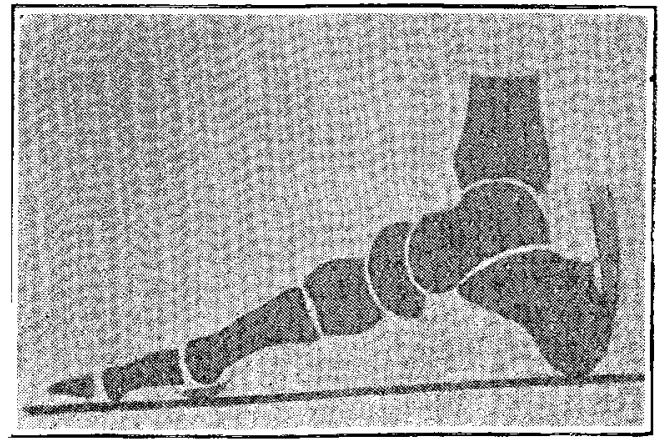

Longitudinal section of the bones of the foot and ankle. (Quain.)

only one small muscle that can effect the latter movement and that it acts at a great mechanical disadvantage. The fore part of the foot is very compressible. Hoffman, of St. Louis, who has studied the feet of a number of bare-footed Philippinos and other half-sarage peoples, gives

3 Transactions of the British Orthopædic Society, rol. iii., p. 44. 
a diagram which shows the degree of painless compression of which the foot of an adult who has never worn shoes is susceptible, and he shows how quickly the adducted great toe of the barefooted man can be brought into abduction or hallux valgus by wearing 'an ordinary boot. Figs. 1 and 2, taken from Quain's Anatomy, represent a longitudinal section of the skeleton of the foot through the great toe and a transverse section of the ankle-joint, under which I have added a section of a peg-top heel. Fig. 2 shows clearly how insecure is the seat of the astragalus on the calcaneum but for the support of ligaments and muscles. When the weight of the body is thrown upon the front of
FIG. 2.

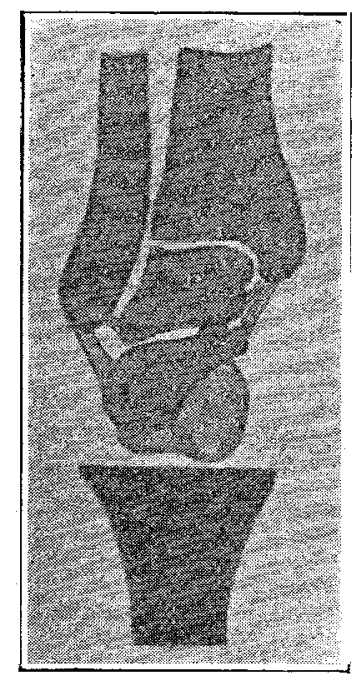

Transverse section of the bones of the ankle and high boot-heel. heel. (Quain.) With
FIg. 3.

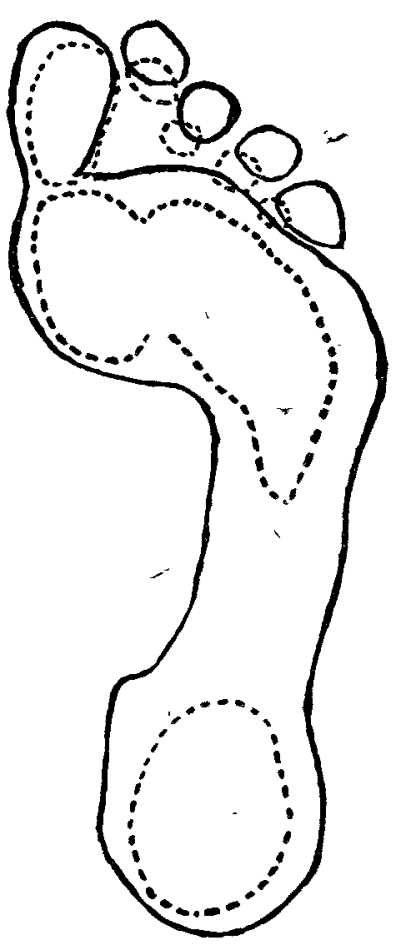

Outlines showing spreading of the foot when loaded. The dotted line shows the loaded mpression. the foot the latter spreads out. In Fig. 3 are shown the outlines of two footprints, taken by blackening the sole with printer's ink and then laying it upon white paper. The broken line shows the extent to which the sole touches a flat surface when bearing only the weight of the leg below the knee (the subject being seated). The unbroken line shows the outline when the weight of the whole body is thrown forward upon it. The respective widths of these outlines are $3 \frac{5}{8}$ and 4 inches, and the length $10 \frac{3}{4}$ and $11 \frac{1}{4}$ inches.

The strain to which the foot is exposed under ordinary circumstances is enormous. Dr. Sampson, of Baltimore, has calculated that supposing the body weight to be $150 \mathrm{lb}$, the strain on the ligaments, taking these as having their effect at a point one-sixth the distance from the summit of the arch to the ground, is equal to $230 \mathrm{lb}$. (Fig. 4.) As the arch yields and is flattened out, this strain increases enormously, until when the arch is almost touching the ground it would amount to $17,475 \mathrm{lb}$, or nearly eight tons. It should be much easier, therefore, to hold up the arch when it is only beginning to give way than when marked flatfoot has developed and the arch has well-nigh disappeared.
The foot of the average boot-wearing adult has been so seriously modified both in its form and in its functions by the fashion of the day acting through its tool the bootmaker, that it has to be considered quite apart from the physiologically normal foot of the bare-footed savage or sandal-wearing Oriental or mocassined red man. This pathological foot is habitually everted, its muscles have to a very great extent lost their functions and have atrophied from disuse, the joints of the toes are more or less stiff and contracted, and this result is especially serious as regards those of the great toe. This, the most important of the digits, can no longer be adducted (towards the mid-line of the body) as it could be in infancy, nor can it be freely extended or flexed, and its owner may be considered lucky if it is not fixed in a position of abduction, presenting the deformity known as hallux valgus. So common has this deformity become that it is regarded by many persons as normal. Evidence of this fact is easily to be found. For instance, in Viollet-le-Duc's great work ${ }^{4}$ already cited, an outline of a pointed shoe is FIG. 4.

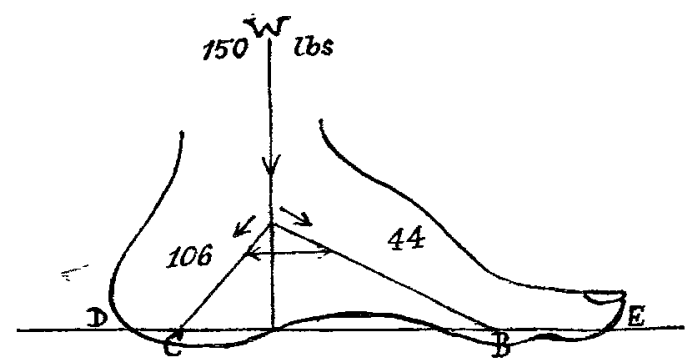

Diagrams showing strain on the plantar ligaments. $w=$ weight of body. The angle $\mathrm{C}, \mathrm{A}, \mathrm{B}$ represents the arch $86^{\circ} .106 \mathrm{lb}$. is transmitted along $\mathrm{A}, \mathrm{C}$, and $44 \mathrm{lb}$ along $A, B$. The strain on the ligaments concentrated at the horizontal arrow $=230 \mathrm{lb}$. (From Sampson's "Proper Footwear," \&c.)

given, which he describes as the shape of the natural foot. It might be expected that anatomists would be more particular than antiquaries or artists, but it is to be feared that they are not much better. In a recent German work on descriptive anatomy, illustrated by excellent coloured plates, those showing the muscles of the sole of the foot represent an abducted great toe. (Fig. 5.) The wonder is, not that so ill-used a member should give trouble and pain, but that it should so generally put up with its abuses without any protest serious enough to be noticed.

The subjects of the arthritic diathesis, as it is called, are peculiarly prone to suffer from painful affections of the feet. Painful flat feet, bunion, hallux flexus or rigidus, metatarsalgia, ingrowing toenails-these are some of the ills that the illshod foot is subject to. It is not heir to them, for the infant's foot is as well formed, its joints as mobile and its muscles as active as that of the bare-footed savage. Besides its original faults, the ordinary boot or shoe soon acquixes others from use. The front part of the sole becomes bent upwards, and if the sole is a stout one this curve becomes so fixed that the plantar flexors of the toes, wasted from disuse, are not able to overcome it. This curve, called "the spring" by shoemakers, is often intentional, especially in heavy boots such. as the army blucher. One consequence of this is that the position of dorsiflexion at the metatarsophalangeal joints, which is temporarily normal in Dr. J. Sobotta in Wirzburg, Band I., Tab. 29. 
the action of walking when the heel leaves the ground, becomes a fixed one, and a rocking action, in which the bent sole is the rocker, takes place. The heads of the metatarsal bones, which are partially uncovered by the dorsiflexed phalanges. have to undergo an undue pressure. Hence corns in the sole of the foot and sometimes metatarsalgia, and in the case of the great toe chronic inflam. mation of the metatarsophalangeal joint and occasionally hallux rigidus. Nor is the boot the only offender, for a considerable effect is produced by stockings and socks as commonly made. These, if they are not a great deal too long, compress the toes to a considerable extent.

Briefly stated, the functions of a proper shoe should primarily be protection from cold, wet, and injury by external objects, and, secondarily, support when from any cause the foot alone is unequal to the strains to which it is liable. Obviously the ideal shoe or boot would be one that fulflled these requirements, without impeding any of the normal functions of the foot. To come to particulars, the shoe should closely and tightly fit the heel and what the French call the neck of the foot, as far forward as the middle of the metatarsus, while it should give plenty of room for free movement of the toes and for the normal spread of the foot when loaded with the body weight. It should above all fit easily across the bunion joint and be what is called straight on the inner edge; that is to say, the forepart of the shoe should be adducted so as to bring the great toe into the line of the first metatarsal bone. And especially is this necessary in cases of flat foot, for owing to the shape and position of the joints between the astragalus and the scaphoid and os calcis respectively, adduction increases, while abduction decreases, the longitudinal arch. A further advantage of the adducted position of the forepart of the shoe is that it brings the great toe nearer to the middle line and under the centre of gravity in the act of walking, and so puts the powerful plantar-flexor muscles in a more favourable position for maintaining the arch and propelling the body forwards. The lower the heel the better-in the first place, because a heel by throwing the weight forwards increases the strain on the arch, as Sampson has shown; and, secondly, because it increases the strain on the lateral ligaments of the ankle (especially the inner, which is less supported by the bones), and so leads to the production of in-ankle.

In Fig. 2 I have added a section of a peg-top high heel to the transverse section of the ankle. This figure shows how much the lateral leverage will be increased by a heel; so that although there is no increased tendency to yield sideways so long as the pile is vertical, yet the moment that one side is lowered by unequal wearing down of the heel, for instance, the increased leverage is likely to play havoc with the relations of the bones of the tarsus. The cheap ready-made shoes that most working women and girls wear have generally high peg-top heels which on examination will be found to be worn down more or less on one side, most often the inner one, and that side of the shoe itself is depressed and deformed, "trodden over," as it is called. It is regrettable that in showrooms and shops there is a dermand for tall girls, to meet which the shorter ones wear highheeled shoes. If these high heels were wide and long and placed well back the evil would be less, but unfortunately all ready-made women's shoes have tapered heels. Perhaps it is not practicable to make a boot fulfilling all the ideal requirements. The normal movements of the foot. must be hampered to some extent by any boot that will keep out the weather and protect the sole from injury. In a light boot the sole may be flexible and the uppers soft enough to allow a considerable range of movement, but in a heavy boot such as the army boot very little movement can be allowed, nor perhaps is it desirable. A tired man carrsing some half a hundredweight will be glad to have his foot and ankle rigidly supported and to avoid all unnecessary muscular effort by using the foot simply as a rocker. Moreover, the necessarily stiff ramp and upper of the army boot allows no movement in the sole, which therefore must have plenty of spring in order to facilitate the rocker action. I am informed that a new boot with a lighter upper is soon to be issued to the army. Fig. 6 represents the sole of a boot designed to meet the above-mentioned requirements. The upper leather is well "boxed up," as it is called technically, over the toes so as to avoid pressure on the nails or the joints. In the case of flat-foct, or of the opposite deformity, cavus or. varus, the boot must be modified.

The right principles seem to have been well understood more than 3000 rears ago, if we may judge from the shoes and sandals which were then worn. In the Egyptian rooms at the British Museum there are long pointed sandals of plaited papyrus 17 or 18 inches long, which suggest the "poulaine" of the late fourteenth century, to which we shall come later. The points of these papyrus. sandals extend on the outer side some 5 inches. beyond the point of insertion of the toe-thong; but behind this the sole is of full width and straight enough. Others are rounded in front of the toe strap, and others again are pointed and turned up at the toe. Some are of the most approved "model" form of to-day; they have an inner edge absolutely straight up to the extreme end and are very wide, measuring approximately $12 \times 5$ inches. There are similar ones of leather slightly narrower. Besides these there are some that are comparatively narrow. One most remarkable pattern has a kind of wicker handle, as it were, which forms the toe and ankle straps, as may be seen in Fig. 7. The point of this sandal is bent upwards and backwards, and attached to the ankle piece, thus closely foreshadowing the fashion of nearly 2000 years later. (No. 4451.) Others (Fig. 8) have in addition side-pieces of papyrus or of leather, which are continuous behind the heel, and these with the recurved toe-piece cover a good deal of the foot and thus the sandal is developing into a boot. These very pointed sandals of various dates would not really have cramped the feet, for the toe-thong was fixed a long way behind the point, which no doubt mainly protected the great toe, and the foot's outer border must freely have overlapped the sole, as there was no upper to constrict it. Compare with these the pointed and recurved Indian shoe from the Victoria and Albert Museum (Fig. 9). No. 4390 is interesting as representing a transition between a sandal and a shoe for a child. It comes from Thebes and is labelled, "Probably about the period of the XXth Dynasty." It has a point turned back and over, a toe-thong or fore-strap and side-pieces of leather continuous round the heel. In front only there is a V-shaped gap, through which the forestrap passes; this gap is partly sheltered by the recurved point of the sole, and thus this sandal is an example in leather of the same pattern as No. 4465 (Fig. 8). In No. 4404 we have a shoe of the 
FIG. 5 .

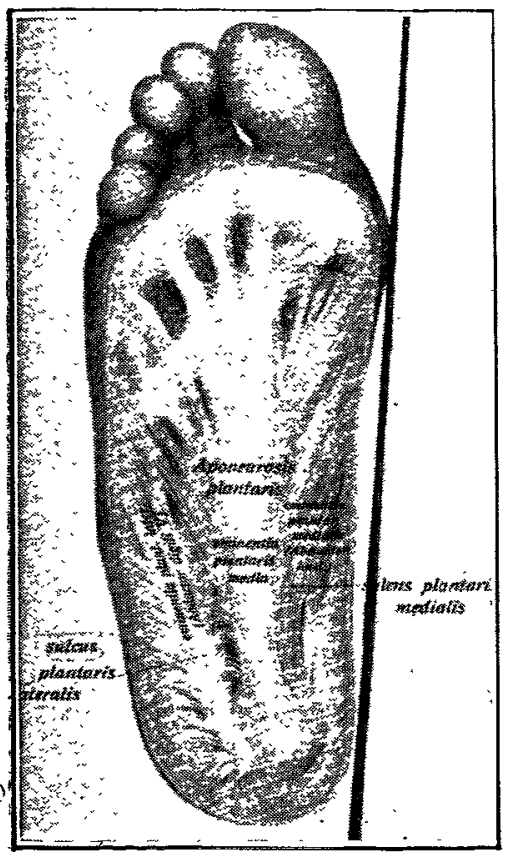

Deformed toes represented as normal. (From Sobbota's "Anatomy.")

FIG. 8.

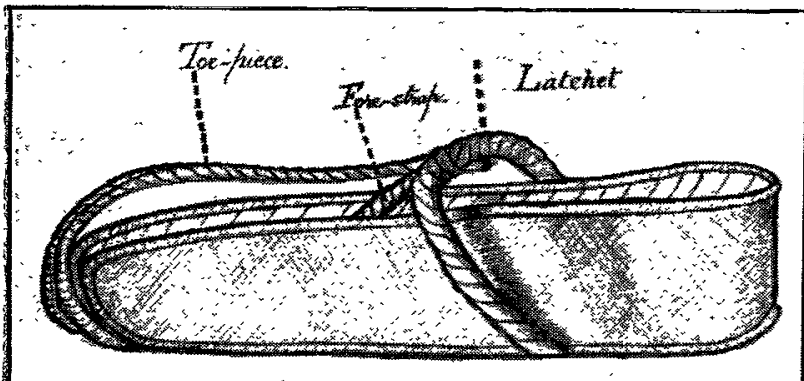

Sketch of papyrus sandal-partially shown in Fig. $7, \mathbf{B}$.

FIG. 9.

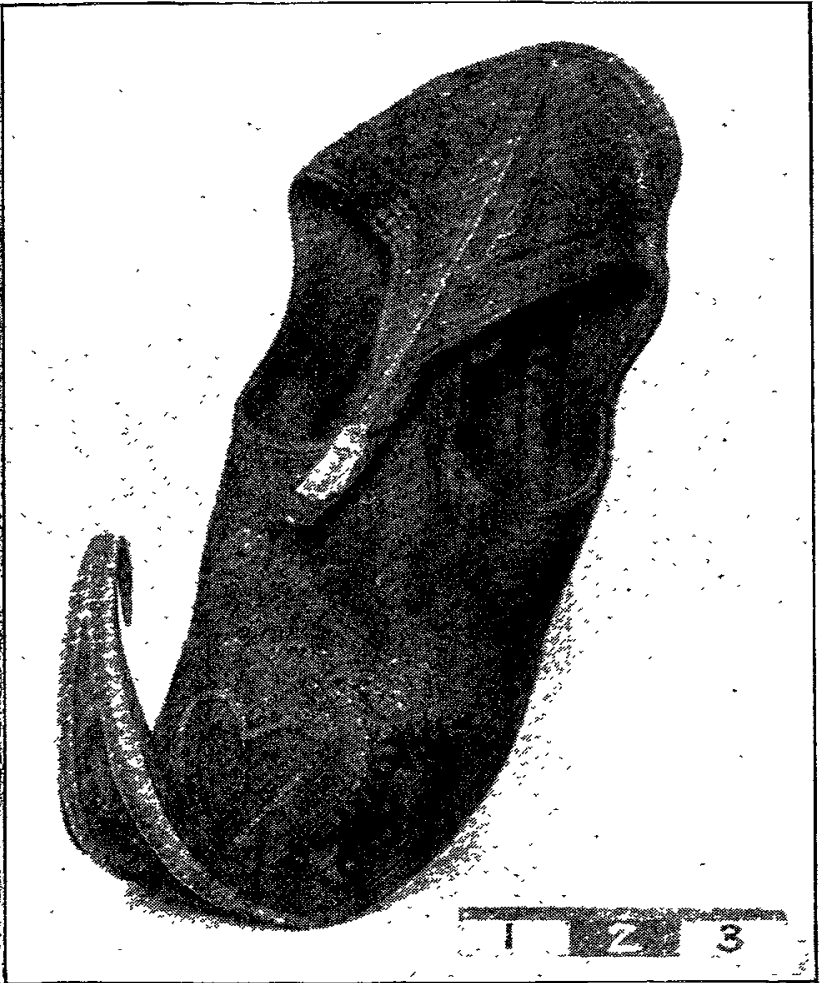

Modern Indian shoe. (Victoria and Albert Museum.)
FIG. 6.

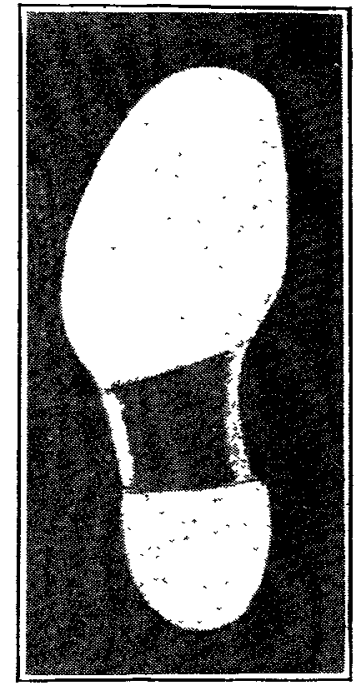

Under-surface of well-shaped boot.

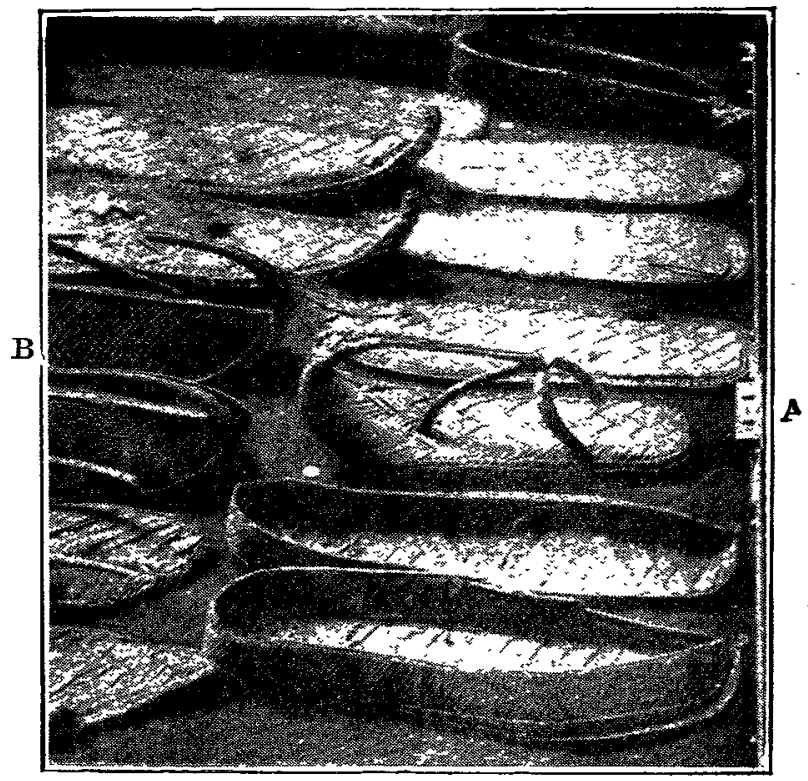

Papyrus sandals. Note A and B. (British Museum.) FIG. 10.

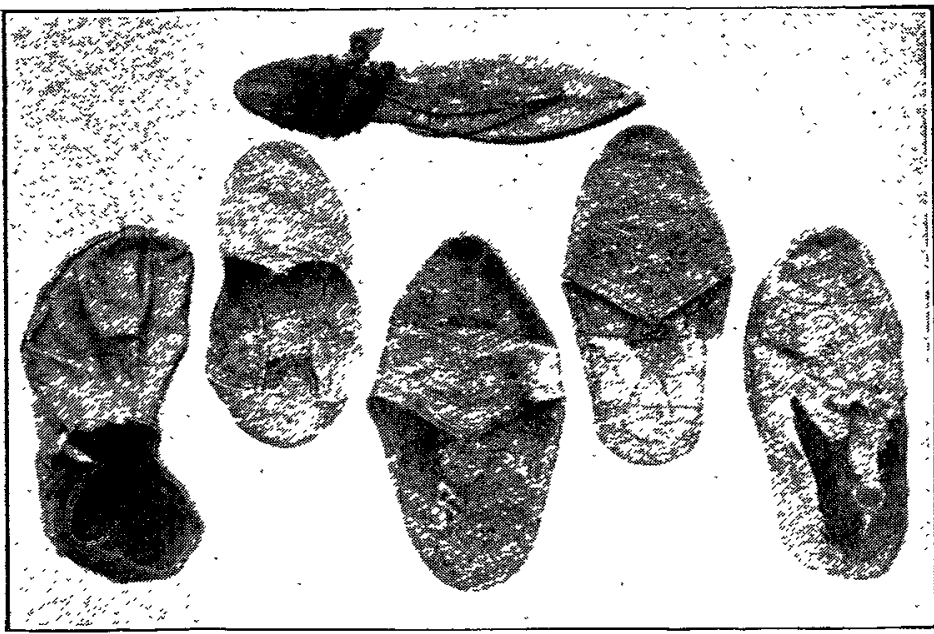

Graco-Fgyptian shoes and clog. (Victoria and Albert Museum.) FIG. 11.

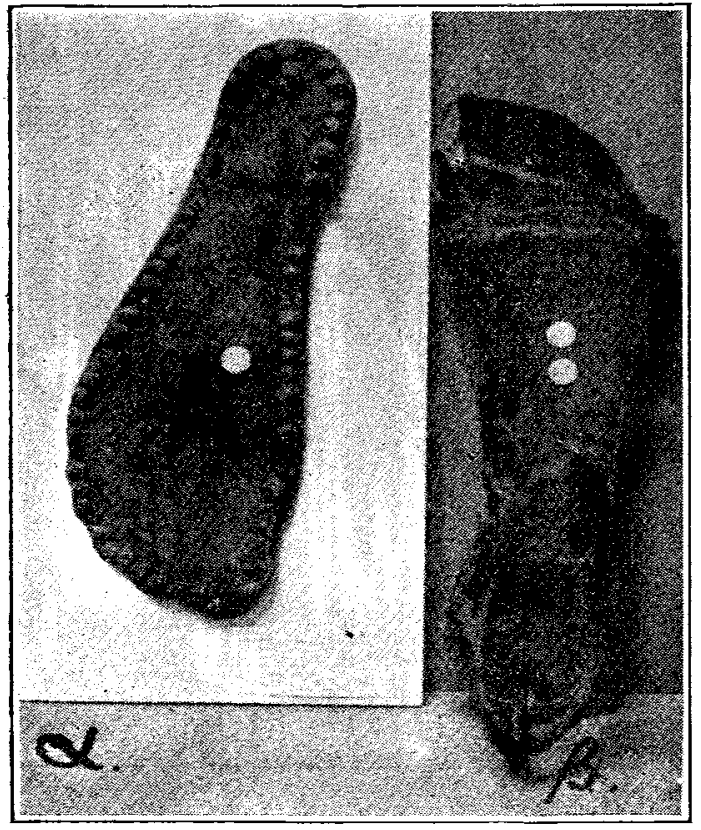

a, Roman sandal. $\beta$, With open-work upper. (Guildhall Museum.) 
FIG. 13.

FIG. 12.



Side view of $\beta$, Fig. 11 .

FIG. 14.

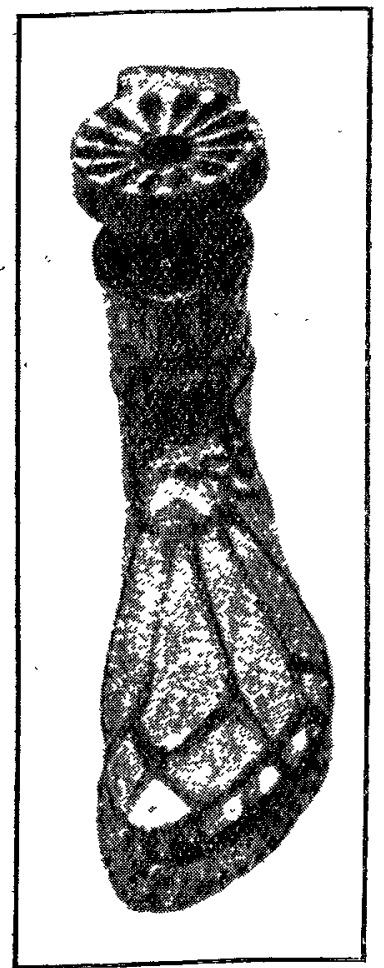

Same as Fig. 13.

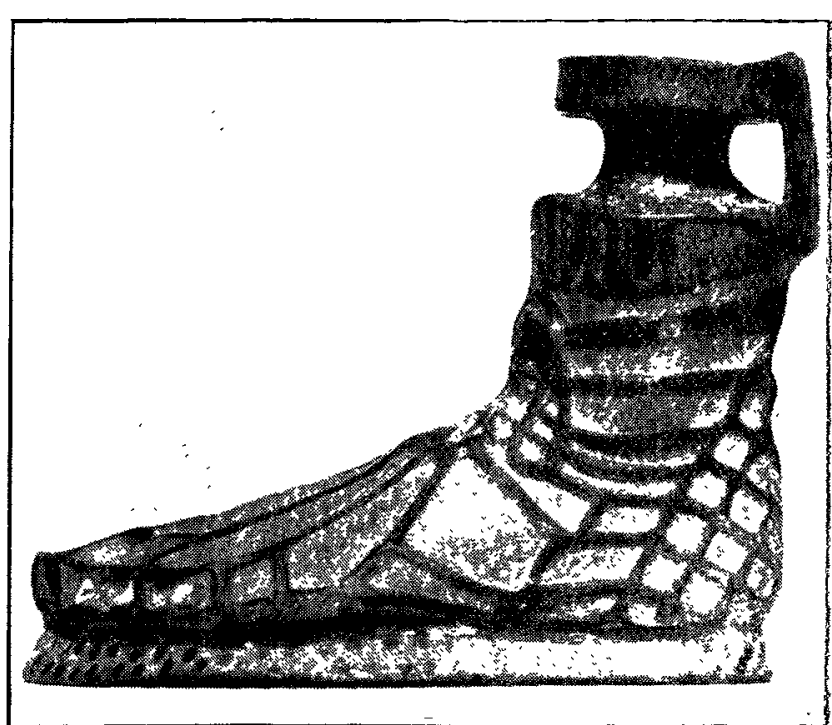

Ancient Greek bottle in the form of a foot. (British Museum.)
FIG. 15.

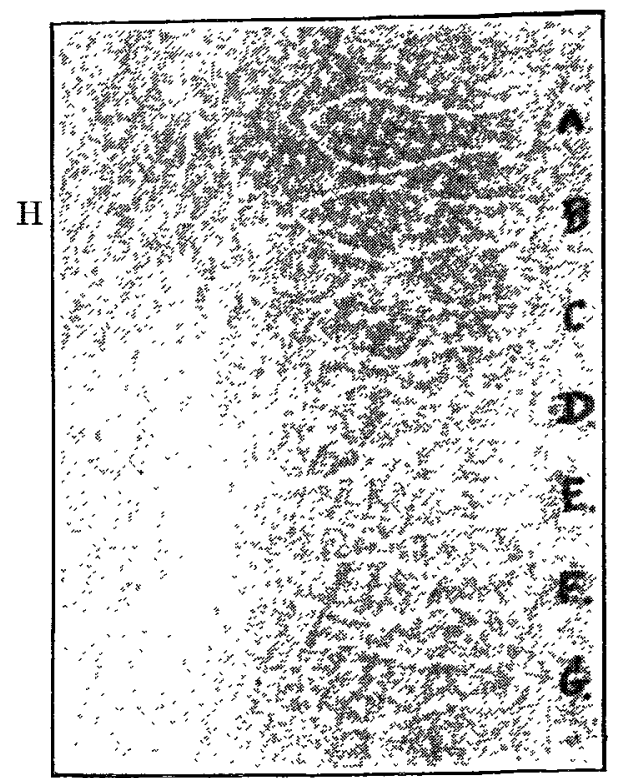

Outlines of shoes of Middle Ages, \&c. (From Viollet-le-Duc.)
FIG. 16.

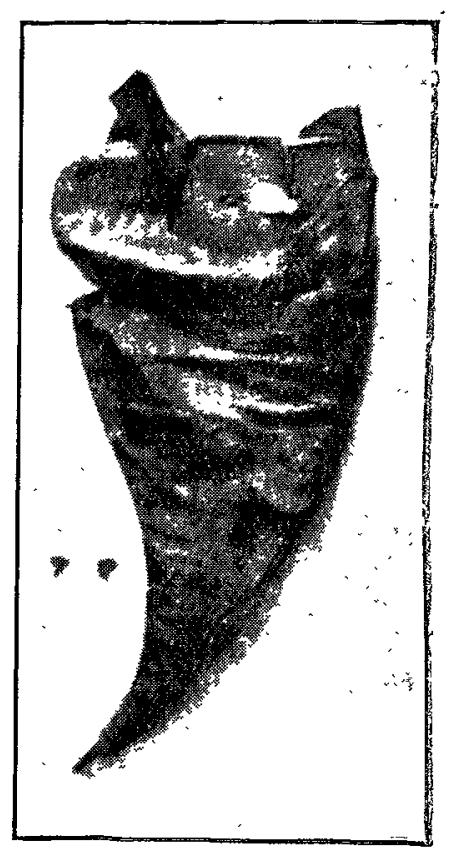

Remains of a "Poulaine." (Guildhall Museum.)

FIG. 18.

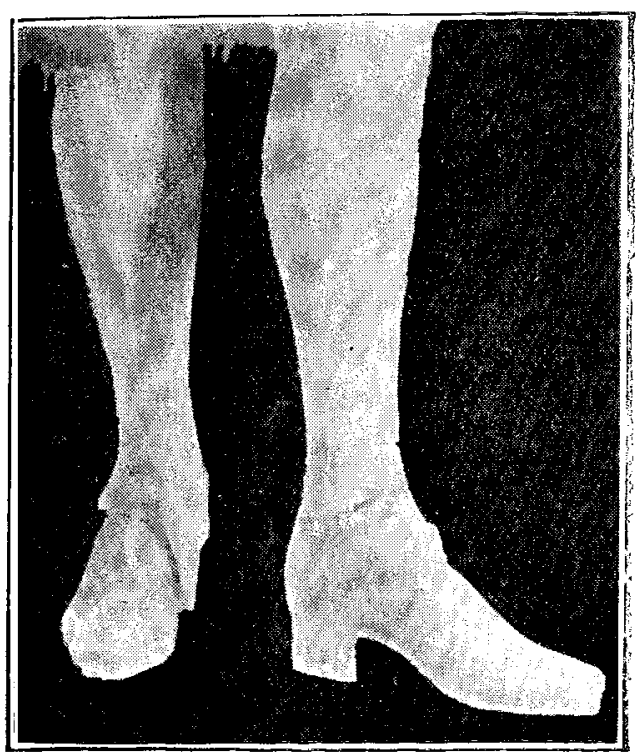

From monument of Lord Mayor Clayton in Bletchingley Church, Surrey. 
Greek period from Thebes, having a complete upper open far enough down to allow of the fore-strap being used, and this completes the series of transition stages between sandal and shoe. This combination of fore-strap and upper might perhaps be revived with advantage now that sandals have come into fashion again for children. In the same case with these really Egyptian sandals are some of the Greek period in Egypt and also of the Roman period. There are some of them pointed, but others are of excellent shape (Fig. 10, from specimens in the Victoria and Albert Museum, shows both forms). Specimens of ancient Mexican sandals in the British Museum are also of good shape.

In the Guildhall Museum of the City of London there are a number of Roman sandals which have been found in excavating for the foundations of modern buildings. In general their shape is excellent, as one would expect of so practical a people. Fig. 11 represents a "sandal for the left foot of three stout soles with Caliga nails round edge, scalloped at toe, found in Wallbrook," while Fig. IIB shows a " sandal of open work with double sole and two rows of nails." Fig. 12 shows a side view of the same sandal. To show the method of attachment of the Roman footgear an ancient Greek bottle in the form of a foot is exhibited in the British Museum. This is clearly shown in Figs. 13 and 14.

To come to a later day, Viollet-le-Duc, in his great work on the furniture and dress of the Middle Ages, figures the sandal of a monk from a sculpture of the first half of the twelfth century. It is straight on the inner edge and has straps between the fourth and fifth toes, as well as between the first and second toes. These straps have loops at their proximal ends, through which and through loops attached to a heel-piece the ankle-strap passes and is then fastened in front. Fig. 15 (copied from Viollet-le-Duc) shows the changing fashions in the shape of soles from the eleventh to the fifteenth century. ${ }^{6}$ A represents the shape in vogue from the end of the eleventh to the beginning of the twelfth century; $\mathrm{B}$, in the midale of the twelfth century; $c$, between 1180 and 1220 A.D. ; D, 1260 A.D. (the curve is exaggerated and the point is more marked) ; E, 1340 A.D. (when the point developed; beginning of poulaines); $F$ and $H$ show the apogee of this strange fashion, from 1370 to 1390 A.D. The poulaine is slightly inclined outwards (like the Egyptian pointed sandal), and when it reached its greatest development, as in $H$, the point was attached by a chain to the $1 \epsilon g$ or to the upper of the shoe, which was high. Viollet-le-Duc writes:-

At the beginning of the reign of Charles the Fifth the poulaine had already increased considerably and this prince believed it to be his duty to forbid the wearing of "trop ultrageuses poulaines." As always happens, Fashion proved stronger than all the edicts of kings and councils. People of low estate were allowed to wear them half a foot long, citizens (bourgeois) one foot, knights one and a half feet, barons two feet. As for princes, they wore them as long as seemed to them good...... The fashion of poulaines extended to armour, so much so that it was impossible for a man at arms to walk. The poulaine, which was very inconvenient, persisted during most of the fifteenth century. It was not until the time of Charles VIII. that this fashion was absolutely abandoned to fall into an opposite excess. Then the soutiers camus appeared, wide at the end and puffed out as in $G$, in the last years of the fifteenth century. During the whole course of the Middle Ages footgear was

6 Viollet-le-Duc: Ibid., rol. iv., p. 334. one of the portions of the dress to which the greatest importance was attached. To be well shod has been in all times the mark of savoir vivre and elegance.

The Guildhall Museum contains specimens of both the pointed and the rounded wide shoe. Fig. 16 shows the remains of what must have been a poulaine, and Fig. $17 \mathrm{~B}$ shows an extreme instance of the Henry VIII. form, measuring six inches in its greatest breadth. Some other specimens in the collection show elaborate pierced decoration. In Fig. 17 is shown the sole of a shoe "clumped with additional sole and heel pieces, with large square-headed nails." This is attributed to the fifteenth or sixteenth century.

We have now arrived at a period when shoemakers and shoe wearers had lost sight of the fact that the two feet, although a pair, are not precisely alike, but that each is the converse of the other. Accordingly shoes and boots were made with little or no difference between left or right. A misguided love of symmetry no doubt was responsible for this, and the fact that both feet must be considered together was overlooked. The heel appeared about this time and superseded to some extent the patten, which had been used out of doors only.

It would be useless to multiply illustrations, but I give one from the monument of Lord Mayor Clayton in Bletchingly Church to show what was long a typical form. Its chief fault is the symmetry of the individual shoe. (Fig. 18.) So recently as 1870 the British army was supplied with shoes and boots the soles of which were almost identical for right and left feet. Fig. 19 is from the sealed FIG. 19.


Sealed pattern of army boot of 1871.

pattern as represented in 1871 in a book by an enterprising shoemaker, James Dowie. The Servian shoes of 1876 (Fig. 20), like the old Highland brogue, have soles of only the same thickness as the vamps and no heels, but they are symmetrically pointed, as are all Chinese boots and shoes, which with their thick quilted paper soles are shown in Figs. 21 and 22. Dr. Hoffman says that the mocassins of the Indians of the United States are straight on the inner side, but the Canadian Indian mocassin, purchased in Montreal, is pointed. Perhaps it was only made to sell to tourists. Fig. 23 shows it in plan and Fig. 24 shows the way it was worn. It is made of soft leather, like wash-leather.

These illustrations will be enough to show that as far back as the extant specimens go the sandal, which may be described as a boot sole without an upper attached to the foot by a simple or complex arrangement of straps, is generally shaped to conform to the outline of the normal foot, while on the contrary boots and shoes are, with few exceptions, so shaped that the foot has to conform to them and thereby to become more or less deformed. The causes of this difference seem to be fairly obvious. The sandal can be most simply and conveniently attached by means of two straps, one transverse 
FIG. 20.

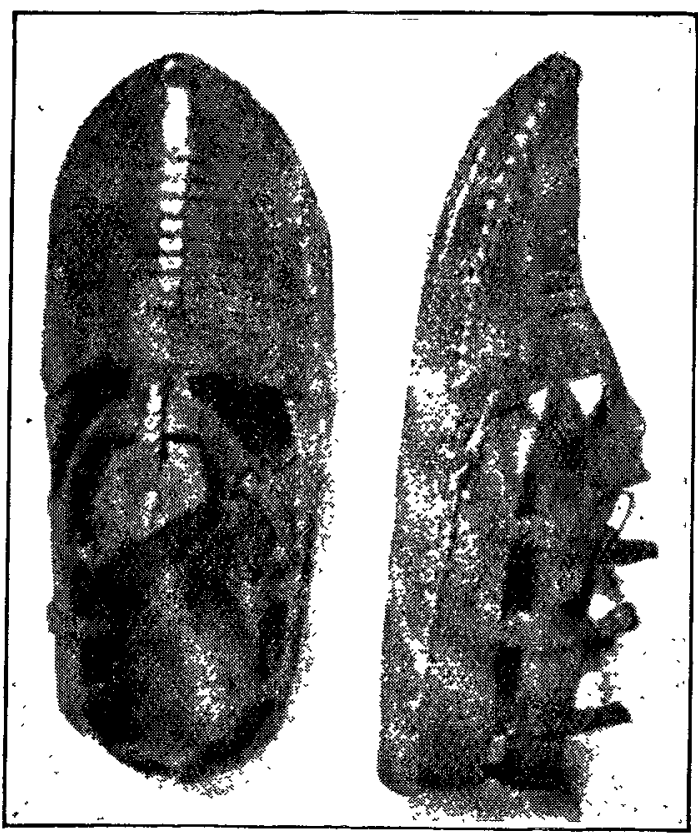

Servian peasant's shoes, 1876.

FIG. 22.

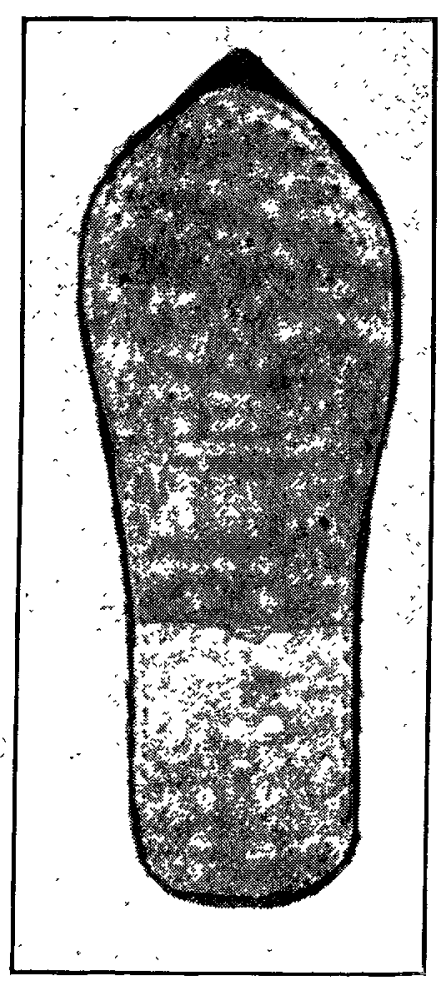

Sole (paper) of Fig. 21.

FIG. 24.

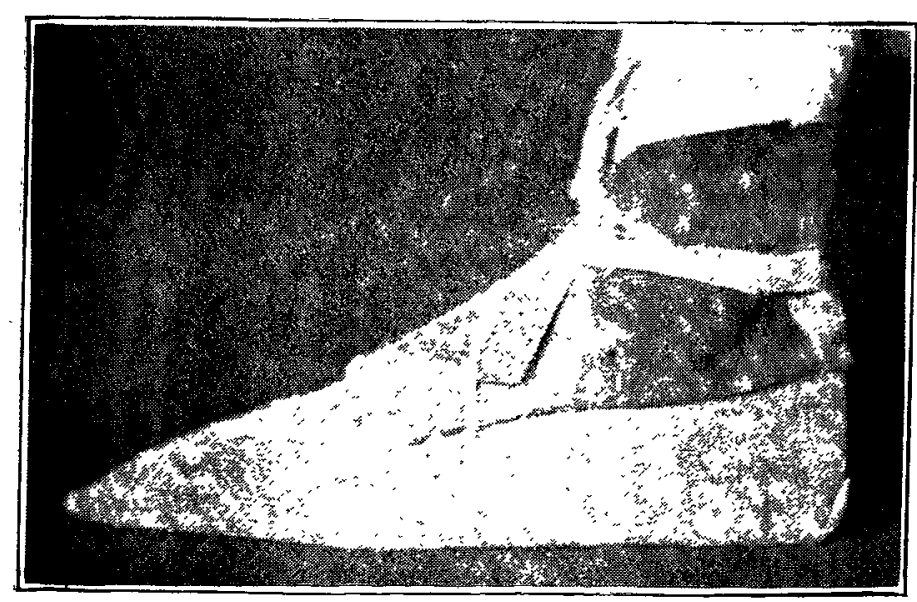

Same as Fig. 23.
FIG. 21.

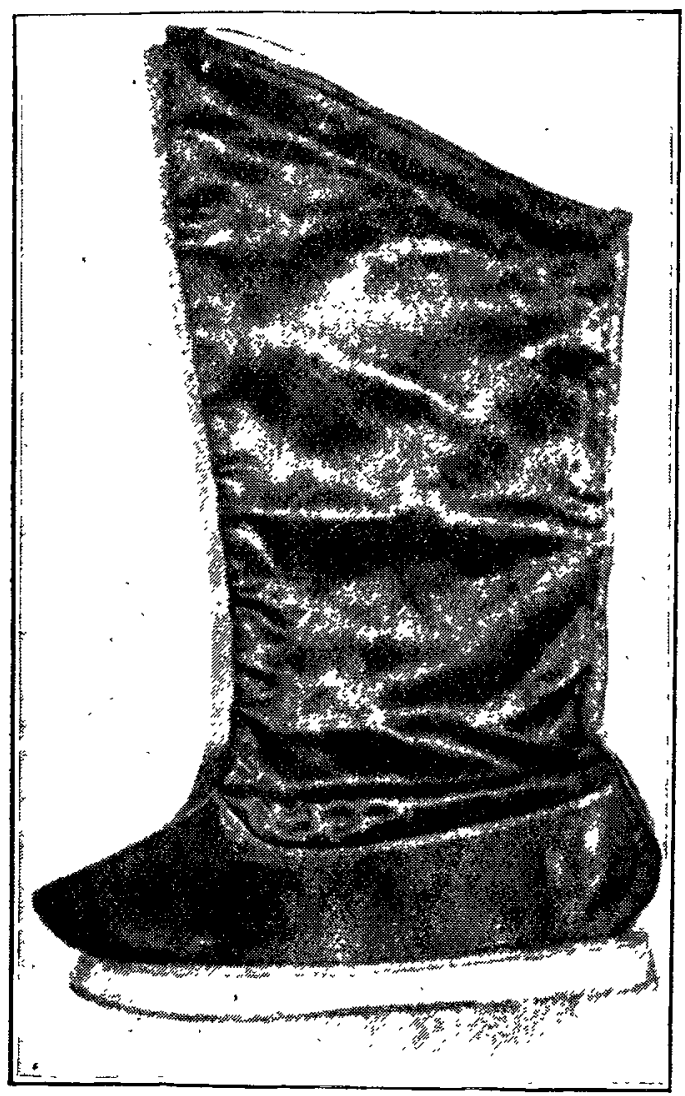

Modern Chinese boot.

FIG. 23.

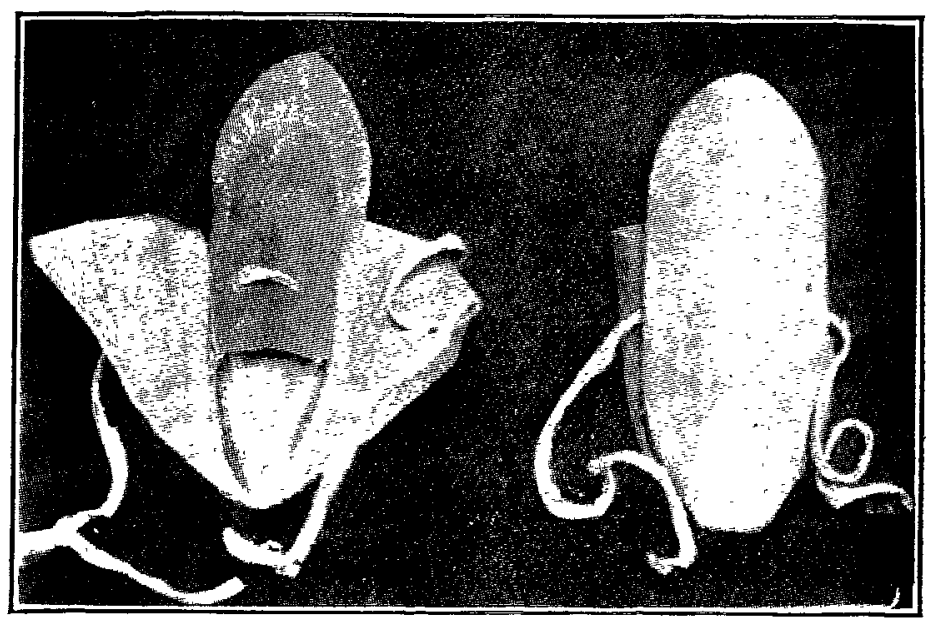

Canadian mocassin.

FIG. 25.

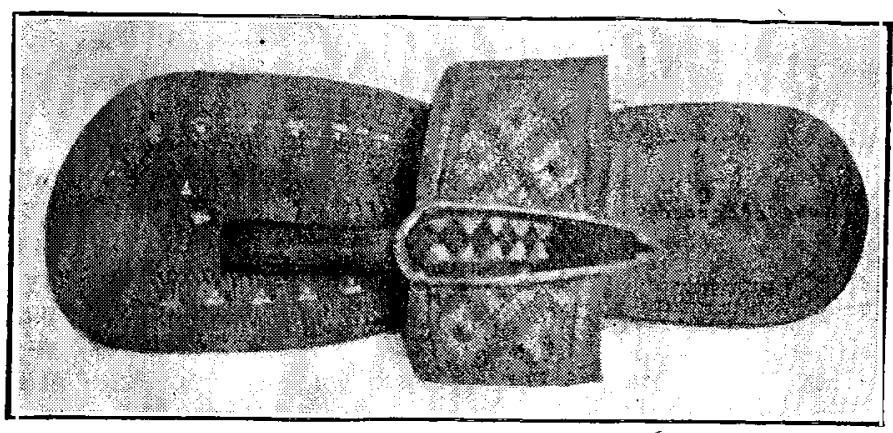

Modern Arau sandal (Zanzibar). 
round the tarsus (the latchet) and another longitudinal between the first and second toes (the forestrap). The modern Arab sandal from Zanzibar (Fig. 25) and the ancient Egyptian (Fig. 7) show this arrangement, while the Roman specimens (Figs. 5 and 6) show the more complicated methods. Such a method clearly does not favour compression of the foot, but, on the contrary, the strap between the toes helps to maintain the adducted position of the pollex. As soon, however, as the shoe took the form of a sheath or casing for the foot, no matter how light or thin it might be, then naturally arose a desire to make it fit " nicely," and in so doing a certain amount of compression was un. avoidable. Unfortunately, the human foot, as Chinese women know too well, is very squeezable, and so we soon arrive at a bilaterally symmetrical shoe, more or less pointed.

A narrow, tight-fitting, pointed shoe is not suitable for hard work, nor is the foot of the labouring man or woman likely to retain a high arch. Consequently, the narrow tight shoe and the high arched foot became marks of the classes who did no manual labour, and therefore signs of aristocracy. Viollet-le-Duc has shown for how many years pointed shoes were in vogue among the fashionable, and that although wide shoes were the fashion in the time of our Henry VIII. their use seems to have been due to a whim and did not long continue. Fashions in dress, especially in the dress of the once softer, but now superior, sex, are usually absurd, and that ever our working girls will adopt a rational form of footgear does not appear hopeful, although there has been some improvement of late years.

This is not the occasion to go into all the modifications of surgical boots required in various diseased conditions, but there are certain simple modifications of the normal boot to which reference may be made. In flat foot the heel and sole may be made continuous on the inner side, in order to prevent that breaking down of the waist of the boot which so often occurs and also to throw the foot on to its outer border. In the same condition the inner border may be raised a quarter or even half an inch; this has a similar effect in a more marked degree. In anterior metatarsalgia, and painful corns on the forepart of the foot whether from claw-foot or any other cause, a simple device will often entirely remove the pain and distress, from which some patients suffer acutely. I refer to the insertion of a flat plate of metal between the welt and the sole, which has the effect of preventing extension of the toes, and generally limiting movewent. Such plates are made of steel, or better of duralumin, which has the advantage of not corroding. If a thin layer of spongy indiarubber is put inside the boot the patient's comfort is still more promoted.

Seymour-street, $W$.

Royal Society of Medicine: Section of DERMATOLOGY. - The following officers of the section of dermatology have been elected for 1914-1915:-President: Dr. J. J. Pringle. Vice-Presidents: Dr. James Galloway, Sir Malcolm Morris, K.C.V.O., Dr. Leslie Roberts, Dr. Edward Stainer, Dr. J. Herbert Stowers, and Dr. Arthur Whitfield. Honorary Secretaries: Dr. S. E. Dore and Dr. A. M. H. Gray. Other members of Council : Dr. Haldin Dr. Davis, Dr. Alfred Eddowes, Mr. Willmott H. Evans, Dr. Wilfrid Fox, Dr. A. D. Heath, Dr. Graham Little, Dr. Henry MacCormac, Dr. J. M. H. MacLeod, Dr. G. N. Meachen, Dr. J. A. Nixon, and Dr. R. B. Wild. Representativer, L Library Committee: Dr. H. G. Adamson. Representative on Editorial Committee: Dr. J. H. Sequeira.

\section{THREE CASES OF MALIGNANT GROWTH AT THE BASE OF THE BLADDER TREATED BY DIATHERMY.}

BY C. E. IREDELL, M.D. LoND., M.R.C.P. LOND., SURGEON TO THE ACTINO-THERAPELTIC DEPARTMENT, GUY'S FOSPITAX AND

RALPH THOMPSON, OH.M. VICT., F.R.C.S. ENG., SURGEON TO THE GENITO-URIXARY DEPARTMENT, GUY'S HOSPITAI.

IN the following paper we desire to draw attention to the very promising results attained by the use of diathermy in three cases of malignant growth in connexion with the base of the bladder. The facts that in two of the cases the very distressing symptoms which are associated with malignant growth of this region have disappeared after repeated large doses of diathermy, and that the patients are in every way so much improved in general health as well as regards the local condition, lead us to suppose that the cases may be worth recording.

The first case attended my (R. T.) out-patient department at Guy's Hospital in September, 1913, being sent for an opinion by Mr. A. Allport. The patient, a man aged 66, was suffering great pain in the perineum. There were painful micturition and very considerable hæmaturia. All the symptoms pointed to some intravesical condition, and as the patient was wasting rapidly and unable to do his work he was admitted with an alternative diagnosis of either enlarged prostate or intravesical neoplasm. The pain and hæmorrhage precluded a cystoscopic examination. The bladder was opened supra. pubically by me (R. T.), and it was found that there was an extensive bleeding mass lying near the orifice of the urethra on the right base of the bladder. Mr. E. C. Hughes, who was kind enough to be present at the operation, agreed with the opinion that unless a very big operation was undertaken the condition was irremovable. The growth was spokeshaved off the surface of the bladder. Bleeding was arrested by the application of boric acid lotion at $120^{\circ} \mathrm{F}$., and the patient was sent back to bed with the usual dressings, a catheter being tied into the urethra. Dr. G. W. Nicholson, of Guy's Hospital, reports that the mass, which was nearly circular and measured 2 inches in diameter by 1 inch deep, is definitely epitheliomatous. Four days after the operation the patient was put undex the influence of gas and oxygen anæsthesia and treated with diathermy (C. E. I.). The method adopted was as follows. A metal electrode about 6 inches square, covered with a thick pad of lint which had previously been moistened with warm water, was placed under the buttocks. The other electrode, which consisted of an insulated stem with a metal bullet-nosed end, was introduced through the suprapubic wound on to the surface of the growth and the current turned on until the part of the growth on which the electrode rested was as hot as could be comfortably borne by the left forefinger introduced at the same time. The whole surface of the growth was treated in this way, and the operation lasted about five minutes on each occasion. This treatment was repeated at intervals of three days until the end of October, when the patient was discharged apparently well. There was no recurrence of the hæmaturia until the end of March, 1914.

The next case is that of a man, aged 54, who came to my (R.T.) out-patient department in December, 